\title{
Sheep performance on perennial lupins over three years at Sawdon Station, Lake Tekapo
}

\author{
A.D. BLACK ${ }^{1}$, G. LOXTON ${ }^{2}$, T.P. RYAN-SALTER ${ }^{1}$ and D.J. MOOT ${ }^{1}$ \\ ${ }^{1}$ Department of Agricultural Sciences, PO Box 85084, Lincoln University, Lincoln 7647, Christchurch \\ ${ }^{2}$ Sawdon Station, PO Box 9, Lake Tekapo, Canterbury \\ alistair.black@lincoln.ac.nz
}

\begin{abstract}
A three-year trial compared the performance of Merino ewes grazing on a perennial lupin pasture with a control flock run predominantly on lucerne pastures at Sawdon Station, Lake Tekapo. At tailing in December, lambing averaged $111 \%$ and ewes averaged $58 \mathrm{~kg}$ for the lupin pasture, and $105 \%$ and $62 \mathrm{~kg}$ for the control flock, while lambs averaged $19 \mathrm{~kg}$ for both mobs. At weaning in February, ewes and lambs on the lupins averaged 58 $\mathrm{kg}$ and $28 \mathrm{~kg}$ compared with $63 \mathrm{~kg}$ and $31 \mathrm{~kg}$ for the control flock, and ewes gained $3.8 \mathrm{~kg}$ compared with $5.5 \mathrm{~kg}$ from March to mating in May. In September, wool averaged $4.62 \mathrm{~kg} /$ ewe for the lupin mob and 4.92 $\mathrm{kg} / \mathrm{ewe}$ for the control flock, with a mean fibre diameter of $18.5 \mu \mathrm{m}$. The average herbage mass on the lupin pasture was $3.0 \mathrm{t}$ dry matter $(\mathrm{DM}) / \mathrm{ha}$ at the start of lambing in October, reached 7.8 t DM/ha in December and decreased to $3.5 \mathrm{t} \mathrm{DM} / \mathrm{ha}$ in May. Results support the use of perennial lupins where lucerne fails to thrive on high country farms.
\end{abstract}

Keywords: high country, liveweight gain, Lupinus polyphyllus, Merino

\section{Introduction}

The perennial lupin Lupinus polyphyllus has been shown to have potential as a pasture legume in high country environments in New Zealand (Scott 2001). It can thrive and fix atmospheric nitrogen $\left(\mathrm{N}_{2}\right)$ in soils throughout the high country of the South Island, even where aluminium $(\mathrm{Al})$ is toxic for most clovers (Trifolium species) and particularly lucerne (Medicago sativa) (Moot \& Pollock 2014; Ryan-Salter et al. 2014). However, limited attempts have been made to quantify the livestock performance (Scott et al. 1994) and feed values (Kitessa et al. 1993) of perennial lupin, with an indication that it has only moderate sheep acceptability, due to its alkaloid content, but sheep adapt to it (Scott 2014).

Sawdon Station, near Lake Tekapo, is one of a few farms in the South Island high country that has been using perennial lupins as a low cost approach to pasture development. The soil on the 7100 ha property is mostly loose-textured and the farm experiences around
140 frosts a year, limiting the options of suitable forage species. The idea of using perennial lupin on the farm was based on the species' ability to tolerate frosts and start growth early in spring, and to survive and fix $\mathrm{N}$ for associated grasses with only $600-650 \mathrm{~mm}$ of annual rainfall and modest inputs of fertiliser and lime. Over the last decade, lupin-clover-grass mixes have been established on Sawdon Station on a commercial scale using the farm's own lupin seed and seed sourced from other growers in mid-Canterbury.

In response to the lack of knowledge around sheep production on perennial lupins, in December 2011 we began a research project on Sawdon Station to determine the performance of Merino ewes and lambs grazing on a 10 ha perennial lupin pasture. These animals were compared with similar animals in one of the main ewe flocks stocked predominantly on lucerne and occasionally clover-based pastures (ca. 200 ha) on the farm. Herbage mass and nutritive values were estimated for the lupin pasture but not for the control pastures. The project continued for 3 years and this paper is a summary of the key results.

\section{Methods}

The lupin pasture was located on a sandy loam, Ashburton fluvial raw soil on a flat lower terrace beside Edward Stream, $6.3 \mathrm{~km}$ south of Tekapo $\left(44^{\circ} 03^{\prime} 54^{\prime \prime} \mathrm{S}\right.$, $170^{\circ} 29^{\prime} 22^{\prime \prime} \mathrm{E}$ and $680 \mathrm{~m}$ above sea level). The annual rainfall is estimated to be $600-650 \mathrm{~mm}$.

The lupins were planted in October 2003 at a sowing rate of $3 \mathrm{~kg} / \mathrm{ha}$ in a seed mix that contained oats, barley, Italian ryegrass and white clover. The seed mix was broadcast with $200 \mathrm{~kg} / \mathrm{ha}$ of Cropzeal $(20 \% \mathrm{~N}, 10 \%$ $\mathrm{P}$ and $12 \% \mathrm{~S}$ ) and incorporated into the topsoil using a Maxi-till. In the first season, the lupin plants were allowed to flower and set seed before grazing. The cereals were harvested in 2004 and over the following years the pasture was grazed leniently to allow the lupins to strengthen and set more seed. In 2010, the lupins were harvested for seed (ca. $400 \mathrm{~kg}$ ), and in 2011 the pasture was fenced into five similarly sized plots for this grazing trial.

While other lupin-clover-grass mixes on Sawdon Station receive modest fertiliser inputs, this lupin 
pasture had been fertilised annually with $200-250 \mathrm{~kg} /$ ha of superphosphate $(9 \% \mathrm{P}, 11 \% \mathrm{~S})$ with or without elemental S, and in 2013 it was dressed with $200 \mathrm{~kg} /$ ha of a mix of lime $(20 \%)$, superphosphate $(40 \%)$, elemental S (40\%) and molybdenum (Mo). A soil test in 2011 showed $\mathrm{pH}, \mathrm{P}$ and $\mathrm{S}$ were optimal and $\mathrm{Al}$ was low (Table 1).

On 12 December, 2011, a group of two-tooth Merino ewes (143) and their lambs (114) was brought on to the lupins. The group rotationally grazed around all five plots with fortnightly shifts. At the same time a two-tooth flock (ca. 800-900 ewes with lambs) was rotationally grazed on predominantly lucerne and occasionally clover-based pastures ("control") nearby on the farm. At weaning on 10 February the ewes and lambs were taken off the lupins to allow recovery of herbage mass. Six weeks later on 23 March the ewes (120) were run back on to the lupin pasture to determine if lupins could be used for flushing and mating. Again this group was rotationally grazed on all plots with 2-week shifts and the control flock was rotated on the lucerne and clover-based pastures. Rams went out on 18 May, the lupins were de-stocked on 20 June, and all ewes were shorn in September 2012.

A longer trial was started on 11 October, 2012, when the 120 pregnant ewes which had grazed lupin were set-stocked on four plots at 16 ewes/ha. Again these animals were grouped together at tailing on 14 December for rotational grazing on all five plots with 2 week shifts - starting in the plot that was not grazed during lambing - until weaning on 18 February. After a 1-month spell the ewes (103) were brought back to continue the grazing rotation (five plots, 2 week shifts). The control flock was run on the same lucerne and clover-based pastures each year. Those ewes were setstocked in lambing mobs of ca. 100 until tailing and then grouped into a single mob (ca. 800-900 ewes) for rotational grazing. Rams went out on 20 May, sheep were taken off the lupins on 20 June, and all ewes were shorn on 19 September 2013.

The third year of the trial started on 10 October, 2013, when 101 of the pregnant ewes which had grazed lupin were set-stocked on four plots at 13.5 ewes/ha. The group rotationally grazed on all plots with 2-week shifts from tailing on 16 December to 27 March, with lambs being weaned on 19 February. After a 1-month spell for crutching, on 24 April the ewes (94) were put back on to the lupins and continued the grazing rotation. Again these animals were compared with the same control flock on the lucerne and clover-based pastures. Rams joined on 19 May and the lupins were de-stocked on 23 June.

\section{Measurements}

Live weights were recorded in October (ewes), at tailing in December and weaning in February (ewes and lambs), and in March/April and May (ewes). Lambing percentages were obtained at tailing as lambs tailed relative to the number of ewes in each mob. All animals on the lupins and a sample of at least 50 ewes and 50 lambs in the control flock were measured at each time. Only averages and sometimes ranges of animal data were recorded from December 2011 to February 2013. On 18 March 2013 all of the lupin ewes (103) and a sample of ewes in the control mob (75) were identified with numbered tags to allow the collection of individual animal data thereafter.

At shearing on 19 September, 2013, the (greasy) fleece weight, staple length and mean fibre diameter ("micron") of individual ewes that were on the lupin pasture during the previous two seasons were compared with the tagged ewes in the control flock. Staple length and micron of mid-side samples were examined using a Fibrescan analyser (Eugene O'Sullivan, Pasture Measurements Ltd, Timaru).

The herbage mass, botanical composition and nutritive value of the lupin pasture were measured in all plots (i.e., including plots the sheep had access to) at monthly intervals during the second and third growth seasons. A $3-5 \mathrm{~m}$ by $1.15 \mathrm{~m}$ strip was cut at three random points per plot to a height of $4-5 \mathrm{~cm}$ using a sickle mower at each time. The cut herbage was weighed fresh and samples were taken back to Lincoln University. Here, $200-500 \mathrm{~g}$ was dried at $65^{\circ} \mathrm{C}$ to calculate the dry matter (DM) percentage to determine herbage mass, and another 200-500 g separated and dried to estimate the composition.

Nitrogen content of 129 samples of lupin, collected in the second season, was analysed using a Variomax $\mathrm{CN}$ analyser, and in vitro dry matter digestibility (DMD) was analysed following the pepsin-cellulase assay. Samples included the separated leaves, petioles, stems, flowers plus green seed pods and dead material of lupin, which had been oven-dried and ground to pass through a sieve with $1 \mathrm{~mm}$ pores.

Table 1 Soil test $(0-7.5 \mathrm{~cm}$ depth) for the perennial lupin pasture at Sawdon Station in 2011.

\begin{tabular}{cccccccc}
\hline $\mathrm{pH}$ & $\begin{array}{c}\text { Olsen P } \\
(\mathrm{mg} / \mathrm{litr})\end{array}$ & $\begin{array}{c}\text { Sulphate } \\
\mathrm{S}(\mathrm{mg} / \mathrm{kg})\end{array}$ & $\begin{array}{c}\text { Exch Ca } \\
(\mathrm{QTU})\end{array}$ & $\begin{array}{c}\text { Exch Mg } \\
(\mathrm{QTU})\end{array}$ & $\begin{array}{c}\text { Exch K } \\
(\mathrm{QTU})\end{array}$ & $\begin{array}{c}\text { Exch Na } \\
(\mathrm{QTU})\end{array}$ & $\begin{array}{c}\text { Exch Al } \\
(\mathrm{mg} / \mathrm{kg})\end{array}$ \\
\hline 6.0 & 24 & 9 & 4 & 25 & 13 & 5 & $<0.5$ \\
\hline
\end{tabular}

*QTU - Quick Test Units 


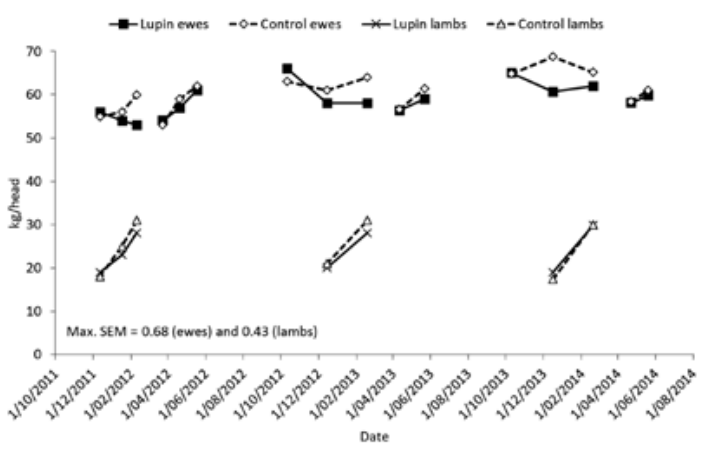

Figure 1 Live weight changes of Merino ewes and lambs grazing on perennial lupins compared with lucerne and clover-based pastures (control) on Sawdon Station. Maximum standard errors of means are given.

Significant $(\alpha=0.05)$ differences in live weight and wool characteristics between the lupin and control groups, for the dates when individual animal data were obtained, were tested by one-way analysis of variance in GenStat 16 statistical software.

\section{Results}

At weaning on 10 February, 2012, the lambs on the lupin pasture averaged $28 \mathrm{~kg}(\mathrm{n}=114)$ and had gained $150 \mathrm{~g} /$ day since tailing on 12 December, while the lambs in the control mob averaged $31 \mathrm{~kg}$ and gained $217 \mathrm{~g} /$ day (Figure 1). The ewes on the lupins lost an average of $3 \mathrm{~kg}$ over the two-month summer period while the control ewes gained $5 \mathrm{~kg}$. Between 23 March and 18 May, the ewes on the lupins gained $7 \mathrm{~kg}(125 \mathrm{~g} /$ day) and the control ewes gained $9 \mathrm{~kg}(161 \mathrm{~g} /$ day $)$.

At tailing on 14 December, 2012, the lambing percentage on the lupin pasture was $103 \%$ compared with $93 \%$ for the control mob, and the lambs averaged 20 and $21 \mathrm{~kg}$ respectively (Figure 1). The ewes on the lupins lost $8 \mathrm{~kg}$ during lambing while the control ewes lost $2 \mathrm{~kg}$. At weaning on 18 February, the lambs on the lupins again averaged $28 \mathrm{~kg}(\mathrm{n}=120)$ and had gained $121 \mathrm{~g} /$ day since tailing while the control lambs averaged $31 \mathrm{~kg}$ and gained $152 \mathrm{~g} /$ day. The lupin ewes maintained weight over the summer period while the control ewes gained $3 \mathrm{~kg}$. Between 11 April and 22 May, the lupin ewes gained $2.6 \mathrm{~kg}$ (64 g/day) and the control ewes gained $4.9 \mathrm{~kg}$ ( $120 \mathrm{~g} /$ day $)$.

At tailing on 16 December, 2013, the lambing percentage was $120 \%$ for the lupin mob and $117 \%$ for the control mob, and the lambs averaged 19 and 17 $\mathrm{kg}$, respectively (Figure 1). The lupin ewes lost $4.3 \mathrm{~kg}$ during lambing whereas the control ewes gained $4.0 \mathrm{~kg}$. At weaning on 19 February, the lambs in both mobs averaged $30 \mathrm{~kg}$ after they had gained $166 \mathrm{~g}$ /day on the lupins and $194 \mathrm{~g} /$ day on the control pastures since tailing. The lupin ewes gained $1.3 \mathrm{~kg}$ while the control

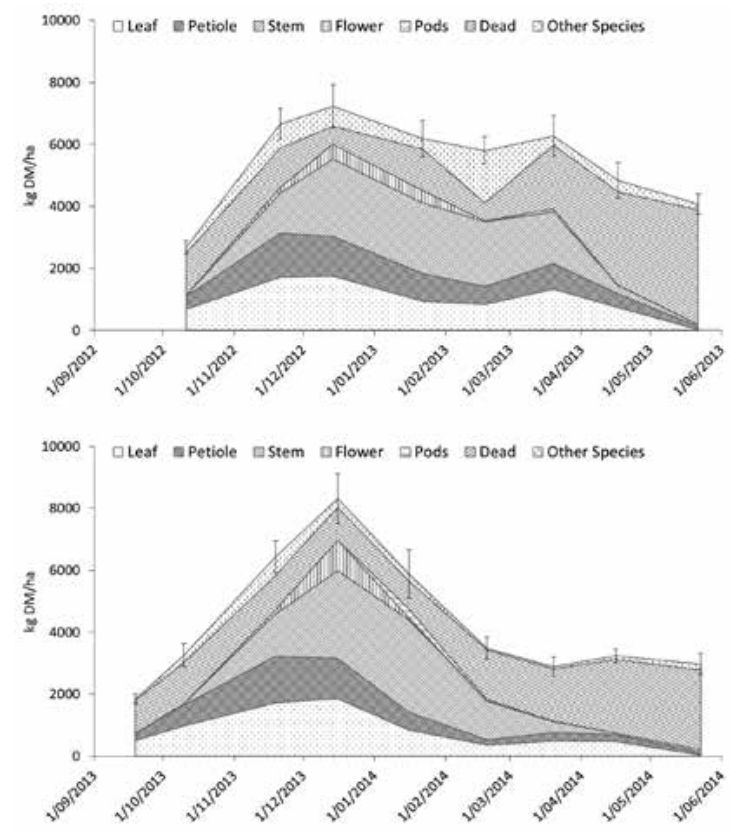

Figure 2 Seasonal pattern of average herbage mass and composition of a perennial lupin stand grazed by Merinos on Sawdon Station. Error bars are standard errors of means for total herbage mass.

ewes lost $3.6 \mathrm{~kg}$. Between 24 April and 19 May, the lupin ewes gained $1.7 \mathrm{~kg}(63 \mathrm{~g} /$ day $)$ and the control ewes gained $2.6 \mathrm{~kg}$ (96 g/day).

At shearing on 19 September, 2013, the fleece weight of the ewes that had been on the lupin pasture during the previous two growth seasons was an average of $4.64 \mathrm{~kg}$ compared with $4.92 \mathrm{~kg}(\mathrm{P}<0.01)$ for the control ewes that had been on the lucerne and other improved pastures. Staple length and mean fibre diameter were similar $(\mathrm{P}=0.373$ and 0.664$)$ at $80 \mathrm{~mm}$ and $18.5 \mu \mathrm{m}$ (Table 2).

In October, 2012, the average herbage mass in the lupin plots was $2.7 \mathrm{t} \mathrm{DM} / \mathrm{ha}$, which increased to a maximum of $7.2 \mathrm{tDM} / \mathrm{ha}$ at tailing in December before decreasing to $5.8 \mathrm{t} \mathrm{DM} / \mathrm{ha}$ at weaning in February (Figure 2). After a 1-month spell the ewes were put

Table 2 Wool characteristics at shearing in September, 2013, of ewes that had been grazing on perennial lupins during the previous two growth seasons compared with ewes that had grazed on lucerne and clover-based pastures (control) at Sawdon Station.

\begin{tabular}{lccll}
\hline & Lupin & Control & SED & P value \\
\hline Fleece weight $(\mathrm{kg})$ & 4.64 & 4.92 & 0.090 & 0.002 \\
Staple length $(\mathrm{mm})$ & 79 & 80 & 1.4 & 0.373 \\
Mean micron $(\mu \mathrm{m})$ & 18.6 & 18.5 & 0.21 & 0.664 \\
\hline
\end{tabular}




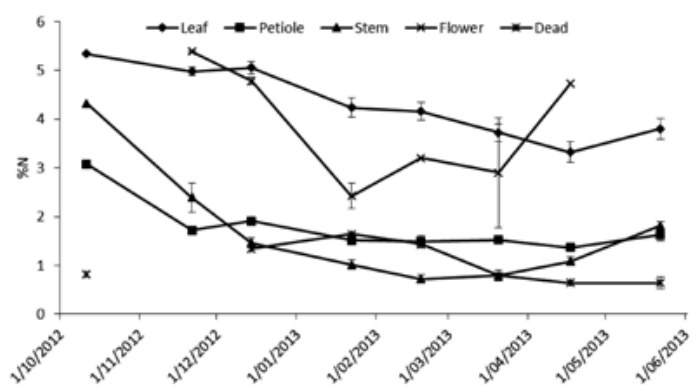

Figure 3 Nitrogen concentrations of perennial lupins on Sawdon Station. Error bars are standard errors of means.

back onto an average of $6.2 \mathrm{t} \mathrm{DM} / \mathrm{ha}$ over all plots in March which decreased to $4.1 \mathrm{t} \mathrm{DM} / \mathrm{ha}$ by May, 2013. The average herbage mass on offer in October was $41 \%$ lupin leaf and petiole, $1 \%$ stem, $51 \%$ dead (mostly lupin stem from the previous year) and 7\% other species. This changed to $42 \%$ leaf and petiole, $35 \%$ stem, $7 \%$ lupin flower, $8 \%$ dead and $9 \%$ other species in December. By February it was 24\% leaf and petiole, $36 \%$ stem, $1 \%$ flower, $10 \%$ dead and $29 \%$ other species. Green lupin decreased and dead stem increased over the 2-month autumn grazing period to the extent that most of the herbage on the trial in May was dead stem.

On 19 September, 2013, the average herbage mass over the lupin plots was $1.9 \mathrm{t} \mathrm{DM} / \mathrm{ha}$, which increased to a maximum of $8.3 \mathrm{t} \mathrm{DM} / \mathrm{ha}$ in December, but then decreased to $2.9 \mathrm{t} \mathrm{DM} / \mathrm{ha}$ in March, when the ewes were taken off the lupins (Figure 2). After the 1-month spell the ewes were returned to an average herbage mass of $3.2 \mathrm{t} \mathrm{DM} / \mathrm{ha}$ across all plots in April which decreased to $2.9 \mathrm{t} \mathrm{DM} /$ ha by May, 2014. The herbage present in September was $40 \%$ leaf and petiole, $58 \%$ dead stem and $2 \%$ other species in September, which changed to $37 \%$ leaf and petiole, $35 \%$ stem, $12 \%$ flower, $13 \%$ dead material and 3\% other species in December. By April it was $22 \%$ leaf and petiole, $1 \%$ green stem and $73 \%$ dead (mostly stem), and by May $4 \%$ was leaf and petiole and $87 \%$ was dead.

Nitrogen content was highest in the leaves and flowers plus green seed pods of the lupins and lowest in the petioles, stems and dead fractions (Figure 3). Leaf $\mathrm{N}$ decreased over the growth season from $5.4 \%$ to $3.8 \%$, petiole $\mathrm{N}$ decreased from $3.1 \%$ to about $1.5 \%$, stem $\mathrm{N}$ dropped from $4.3 \%$ to a minimum of $0.7 \%$ and then increased to $1.8 \%$, and $\mathrm{N}$ content of dead material was always between 0.6 and $1.7 \%$.

Dry matter digestibility of leaves, petioles and stems was $80 \%$ in October, and leaf DMD stayed at $80 \%$ over the rest of the growth season, while petioles and flowers plus seed pods decreased to $60-70 \%$, stems to $45-55 \%$, and dead material was 30-56\% (Figure 4).

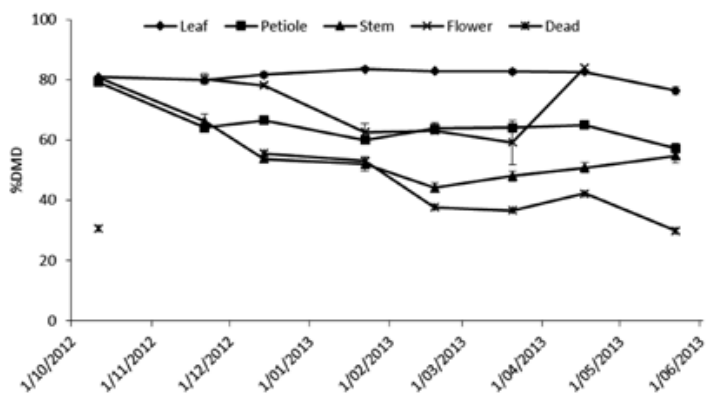

Figure 4 In vitro dry matter digestibility of perennial lupins on Sawdon Station. Error bars are standard errors of means.

\section{Discussion}

The stand of perennial lupins used in this trial had survived under sheep grazing, modest inputs of fertiliser and lime, and $600-650 \mathrm{~mm}$ of rain a year, for 8 years prior to commencing measurements. This result and previous high country research (Scott 1989; Scott et al. 1994) meant we were confident that Merinos would graze on the lupins and the plants would recover from grazing. However, neither the performance of the Merinos nor the quality of the herbage had been recorded. After 3 years of measurement, we now know Merinos on lupins will perform almost as well as Merinos on lucerne and other improved pastures.

The nature of the on-farm trial, in particular the limited information about the pastures offered to the control flock, means our ability to explain differences in sheep performance is limited. Further work is therefore required to clarify the animal production results. However, the trial has demonstrated the performance of Merinos grazing on perennial lupins in their environment, where this lupin species will most likely be used. Also, the additional quantification of herbage mass and nutritive value of the lupin pasture has helped to interpret the sheep performance results. The results have also been a useful extension vehicle, the focus of a field day and visits by Merino growers and industry partners.

With the limitations of the on-farm trial conditions in mind, there are three key results that can be discussed. First, perennial lupins were used successfully as a forage crop for lambing (they also provided tall shelter for new-born lambs), lactation and flushing ewes before and during mating, with acceptable lambing percentages, lamb weights (Figure 1) and wool growth (Table 2). The ewes on the lupins did lose 3-8 kg during the lambing/lactation period and gained $2 \mathrm{~kg}$ less than the control ewes during autumn (Figure 1). A potential lack of leaf material at this time may have contributed. Other possible explanations include differences in stocking rate, feed allowance and grazing preference. However, these results suggest lupin is a viable 
perennial legume for high country environments as an alternative to lucerne.

Second, the lupins started growth in September and provided significant amounts of forage during lambing and lactation under 13.5-16 ewes/ha (Figure 2). The plot that was closed during lambing yielded ca. $8.5 \mathrm{t}$ $\mathrm{DM} /$ ha by the end of November each year. Much of the lupin herbage consisted of green and dead stems, but palatable green laminae and petioles, and grass growing between the lupins, were sufficient to support acceptable lamb growth through to February and ewe growth between March and May each year.

Third, the leaves of the lupins were high in crude protein $(\mathrm{N} \% \times 6.25)$ and digestibility during the entire grazing season (Figures 3 and 4 ). The $\mathrm{N}$ and digestibility values were also high in the flowers plus green pods, but decreased in the petioles (leaf stalks) and stems as the plants developed. These results were expected (Kitessa et al. 1993) and help to explain why more leaves and flowers were grazed by the ewes and lambs than green stem and dead material (based on the herbage composition of plots before and after grazing). The sheep also grazed on the grass among the lupins, but they did adapt to the lupins.

The overall results of this trial demonstrate the potential for perennial lupins to be used on-farm. In addition to these results, agronomic data on sowing rates, fertiliser requirements, grazing management, and survival in a range of edaphic and climatic environments are required to develop a comprehensive extension package. However, results to date suggest attaining such data would be worthwhile to provide Merino growers with a low cost, persistent (Scott 2014) alternative to lucerne.

\section{ACKNOWLEDGEMENTS}

The authors are grateful for funding from NZ Merino Company for year 1 of this trial and from Lincoln University for years 2 and 3. We acknowledge the significant contributions made by Denis Fastier, Eugene O'Sullivan, Dick Lucas, Jim Moir, Mart-Marie Roux, Kate Wilson, Catherine Duchaux and Shuang Jiang.

\section{REFERENCES}

Kitessa, S.M.; Hill, G.D.; Nicol, A.M. 1993 Yield, composition and in-vitro digestibility of Russell lupin. pp. 1801-1802. In: Proceedings of the 17th International Grasslands Congress.

Moot, D.J.; Pollock, K.M. 2014. Perennial lupin establishment and yield when sown at five different rates at Glenmore Station, Lake Tekapo. Proceedings of the New Zealand Grassland Association 76: 5359.

Ryan-Salter, T.P.; Black, A.D.; Andrews, M.; Moot, D.J. 2014. Identification and effectiveness of rhizobial strains that nodulate Lupinus polyphyllus. Proceedings of the New Zealand Grassland Association 76: 61-65.

Scott, D. 1989. Perennial or Russell lupin: a potential high country pasture legume. Proceedings of the New Zealand Grassland Association 50: 203-206.

Scott, D. 2001. Sustainability of New Zealand highcountry pastures under contrasting development inputs 7. Environmental gradients, plant species selection, and diversity. New Zealand Journal of Agricultural Research 44: 59-90.

Scott, D. 2014. The rise to dominance of Lupinus polyphyllus among pasture mixtures in tussock grassland trials. Proceedings of the New Zealand Grassland Association 76: 47-53.

Scott, D.; Maunsell, L.A.; Hunt, L.M. 1994. Relative sheep liveweight gain on perennial lupin, red clover and alsike. Proceedings of the New Zealand Grassland Association 56: 155-157. 